\title{
Arahan Fungsi Kawasan Hutan yang Optimal dalam Rencana Tata Ruang Wilayah Kota Palangka Raya melalui Pendekatan Analisis Spasial
}

\author{
Sari Marlina \\ Dosen Program Studi Teknik Lingkungan Universitas Muhammadiyah Palangkaraya
}

\begin{abstract}
ABSTRAK
Penelitian ini bertujuan untuk mengkaji arahan fungsi dan menghasilkan peta yang berisi zonasi-zonasi fungsi kawasan hutan yang optimal di wilayah Kota Palangka Raya sesuai dengan kondisi eksisting melalui pendekatan analisis spasial dengan koordinasi kepada pemerintah daerah, swasta dan masyarakat terhadap kondisi lapangan dan dapat menghasilkan peta yang berisi zonasi-zonasi fungsi kawasan hutan optimal yang dapat menjadi salah satu referensi, arahan dan pertimbangan teknis untuk manajemen pemanfaatan sumberdaya lahan dan pengembangan wilayah dalam perencanaan tata ruang wilayah di Kota Palangka Raya. Metode penelitian dilakukan dengan tumpang susun peta kelerengan, jenis tanah dan curah hujan menggunakan analisis spasial sistem informasi geografis yang dilakukan dengan sistem skoring sehingga akan didapatkan zonasi-zonasi hasil kombinasi ketiga faktor tersebut. Zonasi-zonasi ini sekaligus merupakan jumlah nilai skoring yang telah diberikan pada ketiga faktor tersebut diatas. Hasil zonasi-zonasi ini kemudian dikelompokkan ke dalam jenis fungsi kawasan hutan sesuai dengan kriteria yang telah ditetapkan dan dikombinasikan dengan kondisi di lapangan. Hasil penelitian memberikan informasi bahwa fungsi kawasan hutan yang optimal di Kota Palangka Raya dengan metode analisis spasial dan memperhatikan kondisi eksisting, yakni seluas 184.178 hektar atau 68,76 persen yang terbagi atas Taman Nasional Sebangau seluas 47.316 hektar atau 17,67 persen, Taman Wisata seluas 533 hektar atau 0,207 persen, Taman Hutan Raya seluas 1.137 hektar atau 0,42 persen, Hutan Produksi Tetap seluas 47.316 hektar atau 16,72 persen, Hutan Produksi Konversi seluas 90.401 hektar atau 33,75 persen. Arahan zonasi untuk penyusunan rencana tata ruang wilayah Kota Palangka Raya, adalah untuk kawasan lindung seluas 49.123 hektar atau 18,29 persen, kawasan budidaya kehutanan (KBK) seluas 135.192 hektar atau 50,47 persen dan kawasan budidaya non kehutanan (KBNK) atau Areal Penggunaan Lain (APL) seluas 83.673 hektar atau 31,24 persen.
\end{abstract}

Kata kunci : fungsi, kawasan, hutan, tata ruang, spasial

\section{PENDAHULUAN}

Meningkatnya kebutuhan dan persaingan penggunaan lahan untuk keperluan kehutanan, produksi pertanian, perkebunan maupun untuk keperluan lainnya termasuk untuk pemukiman dan infrastruktur memerlukan pemikiran yang seksama dan perencanaan yang tepat dalam mengambil keputusan pemanfaatan yang paling menguntungkan dari sumber daya lahan yang terbatas. Penataan kembali penggunaan lahan yang ada dalam Rencana Tata Ruang Wilayah Provinsi dan Kabupaten/Kota (RTRWP-K) tentunya akan menyangkut berbagai pihak dan masyarakat luas, sehingga keadaan ini sering mengundang munculnya berbagai permasalahan. Khususnya di 
Indonesia (Sandy 1983 dalam Sitorus, 1985) ada sejumlah masalah pokok dalam usaha penataan penggunaan lahan dan lingkungan hidup antara lain adanya kontradiksi antara kebutuhan untuk menjadi pemakai yang lebih luas disatu pihak dan batasan-batasan yang berat demi lingkungan hidup, peningkatan keperluan hidup dipedesaan yang tidak disertai dengan perluasan kesempatan kerja dan terjadi kerusakan tanah karena kurangnya pemeliharaan sebagai akibat dari adanya jarak batin atau status hukum yang terlalu jauh antara penggarap dengan pemilik tanah.

Pengelolaan sumber daya alam kedepan perlu didukung oleh prakondisi yang mantap dan terencana, antara lain perlunya ketersediaan data dan informasi yang akurat dan mutakhir mengenai kondisi sumber daya alam setempat terutama hubungannya dengan topografi, jenis vegetasi, keadaan tanah, iklim dan keadaan sosial ekonomi. Adanya Undangundang Nomor 32 Tahun 2004 tentang Pemerintahan Daerah dan PP Nomor 38 Tahun 2007 tentang Pembagian Urusan Pemerintahan Antara Pemerintah, Pemerintahan Daerah Provinsi, Dan Pemerintahan Daerah dimana disebutkan bahwa daerah memiliki kewenangan dalam pengelolaan sumberdaya alamnya serta adanya kegiatan paduserasi dalam RTRWP, dikhawatirkan akan menyebabkan adanya berbagai perubahan dalam fungsi kawasan hutan sehingga diperlukan review tentang penetapan fungsi kawasan hutan berdasarkan keadaan fisik lahan yang sebenarnya sesuai dengan wilayah bersangkutan.

Rencana penatagunaan hutan didasarkan pada pertimbangan letak dan keadaan hutan, topografi, keadaan dan sifat tanah, iklim serta keadaan dan perkembangan masyarakat. Pengelolaan hutan secara teknis biologis berkaitan dengan upaya pemanfaatan sumber daya alam (komoditas biologis) yang ada didalamnya, sedangkan secara geografis spasial, berkaitan dengan masalah ruang yang menjadi lingkungannya (komunitas biologis).

Aspek tata ruang merupakan hal yang tidak dapat terpisahkan dari pelaksanaan pembangunan, baik dalam perumusan kebijaksanaan strategis, maupun dalam penentuan program pembangunan. Untuk menghindari terjadinya ketimpangan dalam melaksanakan pembangunan di semua sektor, maka penggunaan dan pengelolaan sumber daya alam yang sifatnya beragam harus dilakukan secara proporsional. Hal ini akan dapat dilaksanakan apabila ruang wilayah di setiap daerah telah ditata peruntukannya dan untuk mengoptimalkan penggunaannya disusun peta pewilayahan berdasarkan kesesuaian fungsi dan tata guna lahan dengan mempertimbangkan berbagai aspek.

Mengingat bahwa data dan informasi mengenai kawasan dan kondisi hutan bersifat dinamis, mempunyai volume yang besar maka pengelolaan data dan informasi ini perlu dilakukan dengan memanfaatkan suatu sistem yang dapat dipercaya dan fleksibel. Untuk maksud tersebut diperlukan analisis spasial dengan pemanfaatan Sistem Informasi Geografi (SIG) untuk pengolahan data dan informasi yang bersifat keruangan adalah sangat tepat. Dengan SIG ini maka data dan informasi tentang sumber daya hutan dan kawasan ini dapat disimpan, diperbaharui, diolah, dianalisa dan ditampilkan dengan mudah dan cepat.

Palangka Raya sebagai Ibukota Provinsi Kalimantan Tengah merupakan pusat pemerintahan, pusat aktivitas dan administrasi, pusat perdagangan dan jasa, pusat pendidikan, pusat sosial dan budaya serta pusat pelayanan dan transportasi ke seluruh wilayah Kalimantan Tengah. Dengan luas wilayah $2.678,51 \mathrm{~km}^{2}$ dan penduduk sebanyak 168.449 jiwa, kota Palangka Raya dengan segala potensi dan karakteristiknya merupakan daerah otonom yang wajib sesuai kewenangannya sebagai pemerintahan daerah untuk melakukan urusan yang berskala kabupaten/kota antara lain meliputi perencanaan dan pengendalian pembangunan; serta perencanaan, pemanfaatan, dan pengawasan tata ruang sesuai amanat Undang-Undang 26 Tahun 2007. Disisi lain sampai saat ini penataan ruang untuk fungsi kawasan hutan secara defacto masih mengacu kepada Peta Tata Guna Hutan Kesepakatan tahun 1982 yang dianggap tidak sesuai lagi dengan kondisi aktual di daerah karena "mengebiri"; kepentingan penggunaan ruang untuk peruntukan lain.

Berdasarkan Tata Guna Hutan Kesepakatan (TGHK), Kota Palangka Raya ditunjuk dengan fungsi kawasan Hutan Suaka Alam dan Wisata (HSA-W), Hutan Produksi Tetap (HPT) dan Hutan Produksi yang dapat 
di Konversi (HPK) tanpa menyisakan Areal Penggunaan Lain (APL) atau non kawasan hutan untuk pembangunan infrastruktur kota dan perumahan penduduk. Rencana Tata Ruang Wilayah Kota (RTRWK) Palangka Raya telah ditetapkan untuk periode 19992009 yang semestinya dapat direview kembali setiap 5 (lima) tahun sekali, dimana sejak TGHK tahun 1982 dan RTRWK tahun 1999 telah terjadi banyak perubahan penggunaan yang perlu dilakukan penataan kembali dalam rangka mengoptimalkan fungsi kawasan hutan di wilayah Kota Palangka Raya. Salah satu cara yang dapat dilakukan adalah memperoleh arahan fungsi kawasan hutan yang optimal di wilayah Kota Palangka Raya melalui pendekatan analisis spasial. Sehubungan dengan hal tersebut, maka penelitian ini bertujuan mendapatkan Arahan Fungsi Kawasan Hutan yang Oprimal dalam Rencana Tata Ruang Kota Palangka Raya Melalui Pendekatan Analisis Spasial.

\section{METODOLOGI PENELITIAN \\ Lokasi dan Waktu Penelitian}

Penelitian dilakukan di wilayah di Kota Palangka Raya Provinsi Kalimantan Tengah yang berhubungan dengan keadaan fisik wiiayah, perkembangan dan infrastrukturnya serta keadaan sosial ekonomi masyarakatnya selama 3 (tiga) bulan dan proses analisis data dilaksanakan di Ruang SIG Dinas Kehutanan Provinsi Kalimantan Tengah.

\section{Bahan dan Peralatan Penelitian}

Bahan dan peralatan yang digunakan dalam penelitian ini terdiri dari peta Digital TGHK wilayah Provinsi Kalimantan Tengah tahun 1982 skala 1 : 500.000 oleh Badan INTAG Departemen Kehutanan Jakarta, peta RTRWP Kalimantan Tengah tahun 1999 dan 2003 skala $1: 500.000$ oleh BAPPEDA Provinsi Kalimantan Tengah, peta-peta Tematik Kota Palangka Raya yang berhubungan dengan objek penelitian, softcopy Citra Landsat ETM+7 tahun 2007, Path-Row 118-62, unit komputer dengan perangkat lunak Arc View Release 3.3 dengan nomor register ESRI 798481103576, scanner merk Calcomp, GPS merk Garmin Map-76 CSx degan akurasi 9-30.

\section{Prosedur Penelitian}

1. Mendigitasi peta-peta tematik menjadi peta-peta digital dengan skala yang sama.

2. Melakukan tumpang susun peta kelerengan, jenis tanah dan curah hujan menggunakan sistem informasi geografis.

3. Interpretasi Citra Landsat ETM+7 tahun 2007, bekerjasama dengan Direktorat Jenderal Planologi Kehutanan dengan menggunakan model forest canopy density (FCD) dari Rikimaru dan Miyatake (1996).

4. Mendigitasi peta penggunaan/penutupan lahan hasil interpretasi citra landsat.

5. Menghitung luas masing-masing kawasan pada peta vegetasi dan penggunaan lahan sesuai dengan kriteria kawasan.

6. Menghitung luas masing-masing kawasan sesuai fungsinya pada peta fungsi kawasan hasil tumpang susun peta kelerengan, peta jenis tanah dan peta curah hujan berdasarkan nilai skoring.

7. Pembuatan peta arahan untuk penyusunan rencana tata ruang wilayah Kota Palangka Raya berdasarkan peta fungsi kawasan hutan dan peta vegetasi dan penggunaan lahan, kemudian dihitung luas masingmasing zonasi untuk Kawasan Lindung dan Kawasan Budidaya.

8. Melakukan verifikasi lapangan.

\section{HASIL DAN PEMBAHASAN}

Analisis Zonasi Fungsi Kawasan Pemasukan dan Perbaikan Data

Peta-peta tematik yang ada berupa peta tentang keadaan fisik wilayah Palangka Raya, yaitu peta administrasi, kelerengan, tanah, curah hujan, sarana perhubungan, vegetasi dan perijinan. Informasi ini sangat dinamis khususnya trntang penggunaan lahan dan penataan kawasan, sehingga diperlukan fasilitas mengenai penyimpanan, analisis, dan penyajian data yang berstruktur kompleks dan besar. Struktur data kompleks mencakup jenis data spasial dan atribut, sehingga untuk mengelola data ini diperlukan sistem informasi yang terintegrasi mampu mengelola baik data spasial dan atribut ini secara efektif dan efisien. Sistem ini mampu menjawab pertanyaan spasial dan atribut secara simultan, sehingga keberadaan sistem imformasi yang efisien dan mampu mengelola data yang berstruktur kompleks dan dengan jumlah yang 
besar ini dapat membantu dalam proses pengambilan keputusan yang tepat.

\section{Perbaikan dan Editing}

Perbaikan kesalahan adalah salah satu tahap yang sangat penting dalam pembangunan database. Jika kesalahan tidak diperbaiki dengan benar, maka perhitungan luas dan analisis lainnya tidak akan akurat. Sebagai contoh, polygon yang tidak mempunyai titik label tidak dapat mempunyai atribut deskriptif yang diberikan ke polygon tersebut dan jika polygon tidak tertutup, polygon ini akan bocor kedalam polygon sekelilingnya pada saat kita mengarsir atau memberi warna. Begitu pula apabila koordinat geografi antar peta tidak sama terutama pada titik tertentu yang bisa diindentifikasi dipeta maupun dilapangan, maka pada saat overlay peta tersebut tidak akan bisa matching satu sama lainnya dan garis-garis maupun titiknya akan kelihatan berlapis.

\section{Analisis Fungsi Kawasan}

Peta fungsi kawasan berasal dari hasil proses tumpang susun tiga peta tematik yang ada yaitu peta kelerengan, peta jenis tanah dan peta curah hujan. Ketiga peta tematik digabungkan menggunakan software arcview sehingga menjadi peta baru yaitu peta fungsi kawasan hutan Kota Palangka Raya. Gambar 1 berikut mengambarkan ketiga peta tematik tersebut dalam proses tumpang susun dengan mengunakan perangkat arcview.

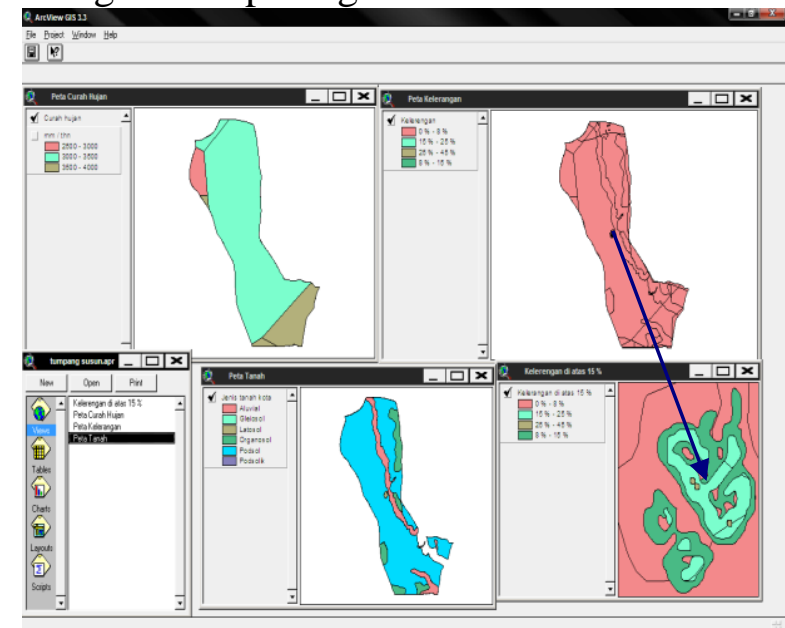

$\overline{\text { Gambar 1. Analisis tumpang susun dalam }}$ penyusunan peta fungsi kawasan hutan di Kota Palangka Raya.

Dari tiga peta tematik yang ada yaitu peta kelerengan, peta jenis tanah dan peta curah hujan yang terdapat pada Gambar 1, dilakukan tumpang susun untuk mendapat nilai skoring kawasan sebagaimana tergambar pada Gambar 2 berikut ini.

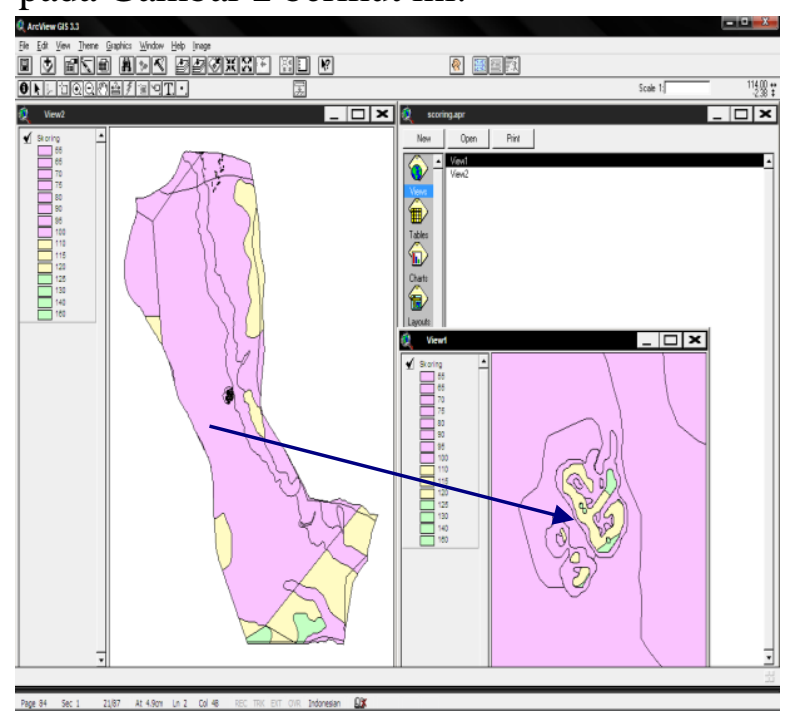

Gambar 2. Hasil Analisis tumpang susun dalam penyusunan peta fungsi kawasan hutan di Kota Palangka Raya berdasarkan nilai scoring.

Berdasarkan perhitungan nilai skoring pada Gambar 2, didapatkan luasan areal untuk masing-masing fungsi kawasan hutan, yaitu untuk Hutan Lindung (HL), Hutan Produksi Terbatas (HPT), Hutan Produksi Tetap (HP) dan Hutan Produksi Konversi (HPK) sebagaimana disajikan pada Tabel 1 .

Tabel 1. Prosentase luas fungsi kawasan hutan di Kota Palangka Raya berdasarkan hasil analisis tumpang susun.

\begin{tabular}{clrrr}
\hline No & $\begin{array}{l}\text { Uraian Fungsi } \\
\text { Kawasan Hutan }\end{array}$ & $\begin{array}{c}\text { Nilai } \\
\text { Scoring }\end{array}$ & Luas (ha) & \multicolumn{1}{c}{$\begin{array}{c}\text { Prosentase } \\
(\%)\end{array}$} \\
\hline 1 & Hutan Lindung & $>175$ & 0 & 0,00 \\
2 & Hutan Produksi & $125-$ & 4.389 & 1,63 \\
& Terbatas & 174 & & \\
3 & Hutan Produksi & $100-$ & 41.659 & 15,55 \\
& Tetap & 125 & & \\
4 & Hutan Produksi & $<100$ & 221.803 & 82,82 \\
& Konversi & -- & 267.851 & 100,00 \\
\hline
\end{tabular}

Selain nilai scoring, terdapat kriteria jika kawasan hutan lindung mempunyai lereng lapangan sama atau lebih dari $40 \%$ atau kawasan yang merupakan daerah resapan air dapat dikategorikan sebagai kawasan lindung, seperti di bukit tangkiling atau lahan gambut di Kecamatan Sebangau. Menurut Ridwan (2000), kawasan hutan yang dapat berfungsi sebagai kawasan wisata berbasis lingkungan adalah kawasan Pelestarian alam (taman nasional, taman hutan raya, taman wisata 
alam), kawasan suaka alam (suaka marga satwa) dan hutan lindung melalui kegiatan wisata alam terbatas dan hutan produksi yang berfungsi sebagai wana wisata. Ekowisata diberi batasan sebagai kegiatan yang bertumpu pada lingkungan dan bermanfaat secara ekologi, sosial dan ekonomi bagi masyarakat dan kelestarian sumber daya alam.

\section{Interpretasi Citra Landsat}

Hasil interpretasi citra landsat Kota Palangka Raya tahun 2007 menghasilkan peta vegetasi dan penggunaan lahan, luasan masing-masing kriteria penggunaan lahan dapat dilihat pada Tabel 2 dan Gambar 3.

Tabel 2. Luas masing-masing kriteria penggunaan lahan di Kota Palangka Raya tahun 2007

\begin{tabular}{|c|c|c|c|}
\hline No & Penggunaan Lahan & $\begin{array}{l}\text { Luas } \\
\text { (Ha) }\end{array}$ & $\begin{array}{l}\text { Prosentase } \\
(\%)\end{array}$ \\
\hline 1 & $\begin{array}{l}\text { Hutan Lahan Kering } \\
\text { Primer }\end{array}$ & 0 & 0,00 \\
\hline 2 & $\begin{array}{l}\text { Hutan Lahan Kering } \\
\text { Sekunder }\end{array}$ & 4.198 & 1.57 \\
\hline 3 & Hutan Rawa Primer & 3.698 & 1,38 \\
\hline 4 & Hutan Rawa Sekunder & 128.200 & 47,86 \\
\hline 5 & Semak/Belukar & 11.849 & 4,42 \\
\hline 6 & Semak/Belukar Rawa & 75.126 & 28,05 \\
\hline 7 & Perkebunan & 1.144 & 0,43 \\
\hline 8 & Pemukiman & 11.442 & 4,27 \\
\hline 9 & Tanah Terbuka & 12.271 & 4,58 \\
\hline 10 & Perairan & 2.298 & 0,86 \\
\hline 11 & Pertanian & 1.607 & 0,60 \\
\hline 12 & Sawah & 499 & 0,19 \\
\hline 13 & Pertambangan & 480 & 0,18 \\
\hline 14 & Rawa & 15.039 & 5,61 \\
\hline & Jumlah & 267.851 & 100,00 \\
\hline
\end{tabular}

Sumber: Interpretasi Citra Landsat ETM+7 tahun 2007, Path-Row 118-62 Wilayah Kota Palangka Raya

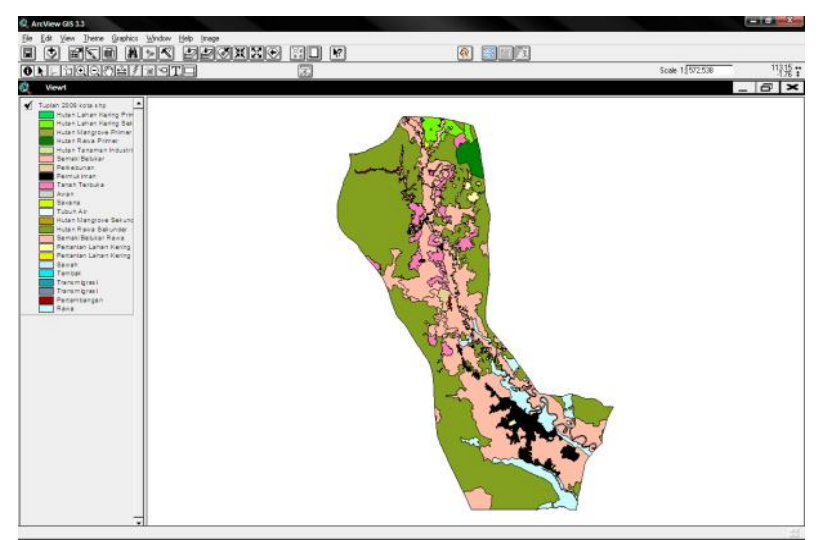

Gambar 3. Interpretasi Citra Landsat ETM+7 tahun 2007, Path-Row 118-62 Wilayah Kota Palangka Raya.
Data dan peta penutupan lahan Kota Palangka Raya di peroleh dari hasil analisis citra landsat tahun 2007 Badan Planologi Departemen Kehutanan yang diretifikasi menjadi peta penutupan lahan Provinsi Kalimantan Tengah dan selanjutnya dicroping untuk wilayah Kota Palangka Raya.

Berdasarkan tabel dan gambar di atas terlihat wilayah Kota Palangka Raya masih didominasi oleh vegetasi berupa hutan rawa sekunder yang terdapat hampir merata di seluruh wilayah kecamatan dan sebagian kecil kawasan hutan rawa primer dan hutan lahan kering sekunder seluas Disamping itu terdapat pula semak blukar, semak belukar rawa dan rawa dan tanah terbuka dengan cakupan areal seluas 114.285 ha $(42,66 \%)$ yang dapat dikategorikan lahan kritis. Pendayagunaan hutan sekunder dan semak belukar merupakan alternatif terbaik daripada eksploitasi hutan primer. Kawasan hutan sekunder, semak belukar dan daerah konservasi tanah dan air sebaiknya dilakukan kegiatan reboisasi dan penghijauan terutama pada daerah-daerah terbuka dan lahan kritis. Kegiatan lainnya berupa pembangunan hutan rakyat berdampak positif terhadap perbaikan sifat kimia tanah yaitu adanya peningkatan kandungan unsur nitrogen dan C-organik pada lahan. Selain itu juga berdampak positif terhadap sikap fisika tanah yaitu adanya peningkatan nilai kapasitas lapangan dan penurunan nilai keratapan lindak (bulk density) tanah. Hal ini berdampak positif pula terhadap penurunan nilai erodibilitasi tanah dan pengendalian laju erosi. Dari segi ekonomi berdasarkan analisis finansial, pola ini layak dan mengguntungkan bagi masyarakat termasuk dengan sistem agroforestry (perpaduan tanaman pertanian dan kehutanan).

Areal pertanian menggunakan lahan seluas $3.250 \mathrm{Ha}$ atau sekitar $1,22 \%$ dari total luas wilayah. Pertanian dalam arti luas yaitu termasuk sawah, tegalan, ladang dan kebun campuran. Wilayah pertanian cenderung tersebar sproradis sesuai wilayah aktivitas masyarakat yang terjangkau. Pendayagunaan lahan pertanian diharapkan tetap menjaga aspek konservasinya mengingat banyak lahan yang dibuka untuk kegiatan pertanian tidak melalui pendekatan teknologi. Terdapat pula penggunaan lahan untuk kegiatan pertambangan seluas 480 atau sebesar $0,18 \%$ 
dari total luas wilayah. Penggunaan lahan pertambangan berada di kecamatan Rakumpit dan Bukit Batu, biasaya pertambangan tradisional seperti galian emas atau zirkon. Potensi kegiatan pertambangan perlu mendapat perhatian pemerintah daerah dalam hal pengaturan dan perijinan agar tidak masuk dalam kategori Pertambangan Tanpa Ijin, mengingat sebagian besar pekerjanya merupakan penduduk lokal yang sudah turun temurun bekerja. Penggunaan lahan berikutnya yang perlu perhatian adalah daerah perairan, berupa sungai, anak sungai, danau-danau yang mencakup areal seluas 2.980 atau sebesar 0,86 $\%$, dimana kawasan ini sangat rentan dengan pencemaran dan limbah baik dari industri rumah tangga maupun dari industri pabrik yang berada di sekitarnya. Sumber daya perairan banyak terdapat potensi ekonomi masyarakat yang dapat di kembangkan antara lain berupa sumber air bersih, tambak, beje dan sebagainya.

Meningkatnya jumlah penduduk dari waktu ke waktu sangat memerlukan penggunaan ruang atau lahan untuk pemukiman termasuk transmigrasi, berdasarkan data pada Tabel 18 di atas di ketahui bahwa areal yang digunakan seluas 11.442 atau sebesar 4,27 \% dari luas wilayah. Pengaturan wilayah pemukiman harus sesuai dengan rencana detail tata ruang agar tatanan wilayah perumahan, sistem drainase, jalan menjadi satu bagian yang sistematik dan berkelanjutan untuk kesejahteraan bersama. Hasil tumpang susun peta fungsi kawasan dan peta penggunaan lahan yang ada di Kota Palangka Raya di dapatkan hasil seperti terlihat pada Gambar 4.

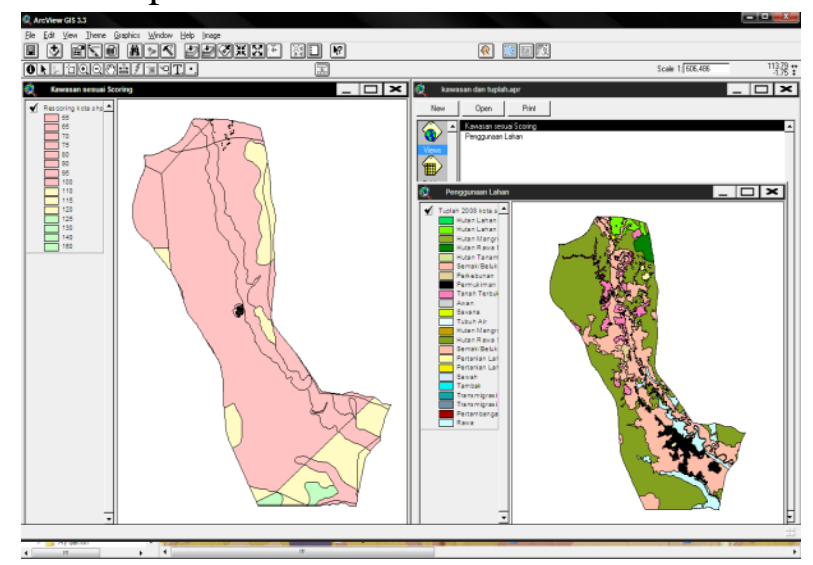

Gambar 4. Tumpang susun peta analisis peta fungsi kawasan dan peta penutupan lahan di wilayah Kota Palangka Raya.
Selanjutnya dari hasil tumpang susun peta fungsi kawasan dan penggunaan lahan yang ada di Kota Palangka Raya pada Gambar $7 \mathrm{di}$ atas di dapatkan hasil seperti terlihat pada Tabel 3 berikut.

Tabel 3. Hasil tumpang susun peta analisis peta fungsi kawasan dan peta penutupan lahan di wilayah Kota Palangka Raya.

\begin{tabular}{|c|c|c|c|c|c|}
\hline \multirow{2}{*}{ No } & \multirow{2}{*}{$\begin{array}{c}\text { Penggunaan } \\
\text { Lahan }\end{array}$} & \multicolumn{3}{|c|}{ Fungsi Kawasan Hutan (Ha) } & \multirow{2}{*}{ Jumlah } \\
\hline & & HPT & HP & HPK & \\
\hline \multirow[t]{4}{*}{1} & Hutan & 0 & 0 & 0 & 0 \\
\hline & Lahan & & & & \\
\hline & Kering & & & & \\
\hline & Primer & & & & \\
\hline \multirow[t]{4}{*}{2} & Hutan & 0 & 57 & 4.141 & 4.198 \\
\hline & Lahan & & & & \\
\hline & Kering & & & & \\
\hline & Sekunder & & & & \\
\hline \multirow[t]{3}{*}{3} & Hutan & 0 & 3.107 & 591 & 3.698 \\
\hline & Rawa & & & & \\
\hline & Primer & & & & \\
\hline \multirow[t]{3}{*}{4} & Hutan & 0 & 24.293 & 103.851 & 128.200 \\
\hline & Rawa & & & & \\
\hline & Sekunder & & & & \\
\hline \multirow[t]{2}{*}{5} & Semak/ & 3.238 & 537 & 11.312 & 11.849 \\
\hline & Belukar & & & & \\
\hline \multirow[t]{3}{*}{6} & Semak/ & 1.151 & 12.777 & 61.198 & 75.126 \\
\hline & Belukar & & & & \\
\hline & Rawa & & & & \\
\hline 7 & Perkebunan & 0 & 0 & 1.144 & 1.144 \\
\hline 8 & Pemukiman & 0 & 1.841 & 9.601 & 11.442 \\
\hline \multirow[t]{2}{*}{9} & Tanah & 0 & 658 & 11.613 & 12.271 \\
\hline & Terbuka & & & & \\
\hline 10 & Perairan & 0 & 7 & 2.291 & 2.298 \\
\hline 11 & Pertanian & 0 & 647 & 960 & 1.607 \\
\hline 11 & Sawah & 0 & 0 & 499 & 499 \\
\hline 12 & $\begin{array}{l}\text { Pertambang } \\
\text { an }\end{array}$ & 0 & 0 & 480 & 480 \\
\hline \multirow[t]{2}{*}{13} & Rawa & 0 & 813 & 14.226 & 15.039 \\
\hline & Jumlah & 4.389 & 41.659 & 221.803 & 267.851 \\
\hline
\end{tabular}

Dari tabel di atas, dapat memberikan gambaran awal bahwa keberadaan hutan sekunder masih banyak terdapat pada fungsi kawasan Hutan Produksi yang dapat di Konversi (HPK) dengan nilai scoring hasil penelitian kurang dari 100 yang umumnya dialokasikan untuk kawasan budidaya non kehutanan, termasuk kawasan pemukiman yang masih mempunyai cakupan luas pada kawasan Hutan Produksi (HP) seluas 1.841 ha. Berdasarkan kajian teknis kehutanan dalam rangka pemantapan fungsi kawasan hutan, dalam pelaksanaan tata batas dan deliniasi di lapangan perlu memperhatikan hak-hak yang sudah ada (kondisi eksisting) yang tidak bertentangan dengan ketentuan yang berlaku, misalnya areal pemukiman dan infrastruktur 
pemerintah seyogianya dikeluarkan atau di enclave dari kawasan hutan termasuk infrastruktur jalan, kantor dan gedung milik pemerintah juga sebaiknya di enclave dari kawasan hutan.

Terdapat pula kebijakan Pemerintah Pusat dan Provinsi terkait dengan penggunaan ruang di Kota Palangka Raya yang semestinya juga di akomodir, yakni :

a. Penunjukan Taman Wisata Alam Tangkiling sesuai Surat Keputusan Menteri Pertanian Nomor: 46/Kpts/Um/1977 tanggal 25 Januari 1977 seluas \pm 533 Ha terletak di Kecamatan Bukit Batu Kota Palangka Raya.

b. Penunjukan Taman Nasional Sebangau di Provinsi Kalimantan Tengah mencakup Kabupaten Pulang Pisau, Kabupaten Katingan dan Kota Palangka Raya sesuai dengan Surat Keputusan Menteri Kehutanan Nomor : SK.423/MenhutII/2004 tanggal 19 Oktober 2004 dengan luas \pm 568.700 Ha terdiri dari Hutan Produksi \pm 510.250 Ha dan Hutan Produksi yang dapat dikonversi \pm 58.450 Ha terletak di Kabupaten Pulang Psau, Kabupaten Katingan dan Kota Palangka Raya.

c. Penunjukan Taman Hutan Raya Nyaru Menteng sesuai dengan Surat Gubernur Kalimantan Tengah Nomor : 1094/SK/460/IX/1999 tanggal 6 September 1999 dengan luas \pm 1.137 yang terletak di Kecamatan Bukit Batu Kota Palangka Raya.

Kajian teknis tersebut di atas, selanjutnya dengan memperhatikan kondisi eksisting yang ada, dilakukan pengambilan sampel pada lokasi-lokasi yang peneliti menganggap strategis di lapangan dengan menggunakan alat Global Position System (GPS) yang selanjutnya diupload sebagai salah satu data spasial dalam kaitannya dengan manipulasi fungsi kawasan hutan yang optimal dan terkini. Data koordinat geografis pengambilan sampel sebagaimana Lampiran 09 hasil penelitian ini.

\section{Analisa Tata Ruang Wilayah Prinsip dan Beberapa Pendekatan dalam Analisa Tata Ruang}

Usaha penataan ruang dimaksudkan untuk memanfaatkan potensi sumber daya alam seoptimal mungkin bagi kesejahteraan masyarakat di wilayahnya melalui pengaturan progam dan proyek secara efisien, baik dari segi lokasi di suatu wilayah, keterikatan antar fungsi kegiatannya maupun keterpaduan dalam pendanaan penanganannya dalam kurun waktu dan kelembagaan bagi pelaksanaannya.

Ruang berfungsi sebagai wadah atau tempat bagi manusia untuk melakukan kegiatan hidupnya. Kegiatan hidup berhubungan dengan usaha manusia memanfaatkan ruang baik sebagai tempat untuk hunian, kerja, eksploitasi sumber daya, kegiatan sosial maupun istirahat. Pemanfaatan tersebut diharapkan dapat berkelanjutan. Dengan kata lain, kemampuan ruang dalam mendukung kegiatan manusia perlu dilestarikan.

Kota Palangka Raya yang mempunyai luas wilayah $267.851 \mathrm{Ha}$ dan sumberdaya alam yang cukup banyak memerlukan penataan ruang yang terencana dan seoptimal mungkin dapat memanfaatkan seluruh potensi dan sumberdaya yang ada untuk peningkatan ekonomi wilayah dan kesejahteraan masyarakatnya.

Ruang dapat dianggap terdiri dari komponen-komponen ruang, masing-masing disebut subsistem ruang yang satu sama lain saling berhubungan dan saling mempengaruhi. Dalam subsistem ruang inilah terdapat manusia dengan berbagai kegiatannya di dalam memanfaatkan sumberdaya yang ada dalam subsistem tersebut. Pemanfaatan yang kurang bijak sana akan memperlemah daya dukung subsistem rung tersebut sehingga dapat mengancam kelestarian kemampuannya dalam menyediakan sumberdaya secara berkelanjutan. Lemahnya satu atau beberapa subsistem ruang akan mempengaruhi hubungan antara subsistem ruang secara keseluruhan. Dengan demikian perlu adanya penataan ruang yang didasarkan pada pelestarian kemampuan daya dukung maupun karakteristik masing-masing subsitem ruang. Dengan cara ini diharapkan terciptanya hubungan yang serasi, selaras dan seimbang antar subsistem. Dengan kata lain perlu adanya penataan ruang yang berazaskan pada keterpaduan. Memperhatikan luas areal kawasan hutan, baik hutan lindung maupun hutan produksi sebesar $177.450 \mathrm{Ha}(66,25 \%)$ seyogianya perlindungan dan pelestarian plasma nutfah dapat terlaksana dan terbangun. 
Analisis Tata Ruang Palangka Raya dalam Konteks Wilayah

Dalam hubungan antar wilayah Kota Palangka Raya, konsep pengembangan tata ruang dilakukan dengan memperhatikan kedudukan Kota Palangka Raya dalam konstelasi yang lebih luas antar kabupaten dalam wilayah provinsi kalimantan tengah dan dengan kabupaten lain di provinsi tetengganya serta indonesia secara umum.

Beberapa dasar pertimbangan dalam konsep tata ruang dalam konteks antar wilayah, antara lain :

a) Palangka Raya sebagai Pusat Pemerintahaan

b) Arah dan kebijakan pembangunan Kota Palangka Raya

c) Kedudukan dan keadaan Kota Palangka Raya secara fisik geografis sebagai ibukota provinsi yang merupakan simpul utama ke seluruh wilayah kabupaten di provinsi kalimantan tengah.

d) Kondisi hidrologi dimana Sungai Kahayan membelah di Kota Palangka Raya, yang memerlukan pengelolaan hidrologi dan kerjasama dengan kabupaten tetangga karena bagian hulunya ada di Kabupaten Gunung Mas yang jika rusak pasti akan sangat berpengaruh pada bagian hilirnya sepanjang alirannya sampai ke muara Sungai Kahayan yang terletak Kabupaten Pulang Pisau.

e) Kondisi dan pengembangan sektor transportasi terutama perhubungan darat dan air antar kabupaten dan provinsi di Palangka Raya.

f) Arahan pengembangan aksesbilitas dan kewilayahan dengan kabupaten yang baru dibentuk secara fisik geografis berdampingan dengan wilayah Kota Palangka Raya yaitu Kabupaten Pulang Pisau, Kabupaten Katingan dan Kabupaten Gunung Mas.

g) Struktur tata ruang provinsi dan nasional.

Kondisi tersebut di atas harus bersinergi dengan perkembangan sektor-sektor ekonomi yang sedang dan akan dikembangkan di Kota Palangka Raya. Besarnya keterkaitan Kota Palangka Raya terhadap wilayah lainnya diindikasikan oleh besarnya barang yang masuk kewilayah ini, terutama dari Provinsi
Kalimantan Selatan yang masuk lewat transportasi darat maupun sungai.

Konsep tata ruang antar wilayah juga tak lepas dari masalah perbatasan dengan kabupaten/provinsi lain yang secara fisik geografis berdampingan dengan Kota Palangka Raya. Masalah ini makin terangkat kepermukaan sejalan dengan otonomi daerah dimana masing-masing kabupaten berusaha menginventarisir dan mengeksploitasi sumberdaya alam yang ada di wilayahnya semaksimal mungkin dengan tujuan diantaranya untuk menambah pendapatan asli daerahnya (PAD). Masalah muncul di daerah perbatasan karena selama ini di tempat yang dianggap batas tersebut tidak ada patok batas maupun titik koordinat yang pasti yang bisa dijadikan dasar akan batas kedua wilayah. Batas tersebut selama ini hanya ada di peta berupa garis yang sangat meragukan letaknya di lapangan.

Mengenai tapal batas wilayah ini, sebaiknya Kota Palangka Raya juga mencermati dan segera merencanakan batas wilayah dengan kabupaten lain yaitu Kabupaten Katingan, Kabupaten Gunung Mas dan Kabupaten Pulang Pisau. Hal ini penting agar dikemudian hari tidak akan terjadi sengketa mengenai perbatasan antar wilayah ini. Alternatif yang paling baik adalah membuat patok batas permanen dengan berdasarkan pada kombinasi antara titik koordinat geografis pada GPS dengan batas alam yang jelas dan diperkirakan tidak akan mudah dan cepat berubah.

\section{Analisis sumberdaya alam dan lahan}

Sumberdaya alam di bumi ini merupakan sesuatu sistem yang sangat luas, kompleks, dinamis, serta berinteraksi satu sama lain. Usaha untuk mengubah salah satu komponen dalam sistem itu akan menimbulkan perubahan dimana-mana dalam sistem tersebut. Lagi pula pengertian manusia terhadap sistam itu masih sangat terbatas. Dengan sendirinya sulit untuk meramalkan apa yang akan terjadi dengan usaha untuk memanipulasi sistem tersebut. Jadi hubungan sebab dan akibat sulit dimengerti. Suatu tindakan belum tentu menimbulkan akibat seketika, dan baru dirasakan akibatnya setelah melampaui beberapa waktu. Akibat dari suatu tindakan sulit untuk diramalkan, padahal sekarang ini 
kemajuan teknologi sangat cepat sehingga akan sering menimbulkan adanya perubahanperubahan baru yang sulit pula diramalkan akibatnya.

Dalam proses pertumbuhan wilayah di Kota Palangka Raya baik ditinjau dari dimensi ruang ekonomi maupun dimensi geografi, peranan sumberdaya alam dan lahan memberikan input yang besar terhadap pertumbuhan sektor-sektor ekonomi lainnya. Untuk ini prinsip keseimbangan eksploitasi sumberdaya alam dan lahan dengan lingkungan hidup harus diterapkan agar rasionalisasi dalam pengelolaan sumberdaya alam secara lestari dapat merupakan bagian intergal dalam upaya pembangunan wilayah di Kota Palangka Raya.

Analisis sumberdaya alam merupakan kegiatan inventarisasi dari potensi sumberdaya utama dan poternsi sumberdaya utama dan potensi dampak dari kegiatan tersebut. Hasil inventarisasi ini akan memberikan pandangan tentang kondisi sumberdaya wilayah Kota Palangka Raya. Potensi sumberdaya alam berupa mineral cukup besar dan baru sebagian yang telah dieksploitasi. Jenis-jenis sumberdaya mineral yang ada diantaranya adalah batu bara, emas, intan, kapur, nika, anti monit, kaolin dan bentonit serta bahan galian dari jenis golongan $\mathrm{C}$ lainnya.

Meningkatnya kebutuhan lahan untuk kegiatan-kegiatan pembangunan maupun kegiatan masyarakat, telah menimbulkan gejala konflik peruntukan lahan antar sektor. Berkaitan dengan itu, maka perlu dikembangkan mekanisme yang mengatur pemenuhan kebutuhan lahan yang diperlukan baik yang berkenaan dengan aspek fisik maupun penguasaan lahan. Untuk kegiatankegiatan pembangunan yang berkaitan dengan peruntukan dan penggunaan lahan dapat diselesaikan melalui koordinasi dan keterpaduan antar sektor-sektor pembangunan dan kelembagaan dengan selalu melibatkan partisipasi masyarakat. Kemudian dalam rangka menjaga kualitas sumberdaya lahan, penggunaannya harus dilakukan dengan hatihati mengingat sumberdaya ini rentan terhadap perubahan dan sangat terbatas.

\section{Analisis Sumberdaya Hutan}

$\begin{array}{cccr}\text { Secara } & \text { ilmiah } & \text { struktur } & \text { dan } \\ \text { perkembangan } & \text { vegetasi } & \text { (semua } & \text { jenis }\end{array}$

tumbuhan/flora yang tumbuh disuatu tempat) dipengaruhi oleh faktor lingkungannya. Vegetasi sangat cepat bereaksi terhadap perubahan keadaan sekitar. Perubahan ini tentu akan bertambah besar bila terjadi perubahan lingkungan yang berkaitan dengan adanya kegiatan pembangunan dimana vegetasi itu berada maupun vegetasi yang ada sekitarnya.

Demikian juga untuk parameter yang lain seperti densitas. Densitas komunitas tumbuhan tertinggi berada di hutan-hutan sepanjang khatulistiwa atau dikenal dengan nama hutan tropis. Dengan densitas dan diversitas yang tinggi memungkinkan tingginya komposisi serasah, sehingga menyebabkan dekomposisi yang tinggi pula. Dekomposisi yang tinggi akan mempengaruhi fertilitas tanah sehingga akan menjadi sumber mineral yang kembali diperlukan oleh komunitas tumbuhan. Kesuburan komunitas tumbuhan berpengaruh terhadap tingginya diversitas organime yang menghuni di dalamnya sebagai tempat berlindung, mencari makan maupun berkembang biak. Hutan mempunyai fungsi yang beraneka ragam antara lain sebagai penghasil kayu dan hasilhasil hutan yang lain serta pelindung lingkungan yang berfungsi mengatur tata air, melindungi kesuburan tanah mencegah erosi dan lain-lain. Prinsip kelestarian yang terkenal dengan konsep maximum sustainable yield telah lama dikenal dalam bidang pengelolaan sumberdaya alam.

Hutan dapat didefinisikan sebagai asosiasi masyarakat tumbuh-tumbuhan dan hewan yang didominasi oleh pohon-pohonan dengan luasan tertentu sehingga dapat membentuk iklim mikro dan kondisi ekologi tertentu (Suparmoko, 1995). Hutan merupakan sumberdaya biologis yang terpenting diatas bumi. Air merupakan produk penting dari hutan, tanah di hutan merupakan busa raksasa yang mampu menahan air hujan sehingga air merasap perlahan-lahan kedalam tanah. Banyak kota yang menggantungkan diri terhadap persediaan air dari hutan dan sungaisungai yang mengalir sepanjang tahun. Tetapi bila pohon-pohon dihutan ditebang, maka tanah langsung terbuka sehingga bila hujan turun, air hujan langsung mengalir kesungai dan menyebabkan erosi maupun banjir. Margasatwa juga merupakan sumberdaya yang ada dihutan. Hutan memberikan makanan dan 
perlindungan terhadap banyak macam burung dan binatang lainnya. Demikian pula jutaan manusia menggantungkan hidupnya pada hutan sebagai sumber pangan maupun tempat rekreasi. Sifat hutan yang memiliki penggunaan ganda itu berkaitan dengan sifat hutan yang cukup unik yang merupakan fungsi hutan yang bisa memberikan manfaat langsung maupun tak langsung.

Deforestasi merupakan hasil berbagai macam kekuatan penggerak, namun proses deforestasi berskala besar yang paling mengancam disebabkan oleh tekanan kemiskinan dan tekanan eksploitasi hutan secara berlebihan. Berbagai masalah sosial yang tak terpecahkan seringkali mengkondisikan kebiasaan untuk menghambur-hamburkan sumberdaya alam. Kecenderungan positif terhadap lingkungan dapat disebabkan dari penerapan manajemen hutan dengan melibatkan masyarakat. Kecendrungan positif ini ditandai dengan adanya perbaikan biodiversitas, pasokan air dan mencegah erosi tanah ada cakupan yang luas untuk memperbaiki pemahaman dan pemantautan pengaruh yang ditimbulkannya.

Jika sebuah hutan diubah menjadi perkebunan dengan satu jenis pohon (mono kultur), umpamanya karet atau kelapa sawit, besarnya zat hara yang hilang sebagai berikut: kalsium 62\%; Potassium 75\%; fospor 30\%; nitrogen $50 \%$. Selanjutnya, hilangnya hutan berarti juga hilangnya efek penyangga untuk menahan arus air permukaan sewaktu hujan lebat. Hal ini mengakibatkan sedimentasi dan banjir yang lebih parah di hilir sungai. Kondisi saat bersamaan, tanda-tanda kekurangan air pada musim kemarau juga semakin jelas, karena rusaknya kapasitas tanah untuk menahan air, menyebabkan jumlah air yang mengalir kesungai dan anak-anak sungai selama musim kemarau menjadi sangat berkurang.

Karena itu dalam perencanaan pemanfaatan sumberdaya alam berupahutan harus dipertimbangkan pengaruhnya (akibatnya) terhadap daerah bawah tanah (down stream) tentang kemungkinan berkurangnya produksi air yang disebabkan karena eksploitasi hutan yang tidak terkendali maupun eksploitasi sumberdaya alam lainnya, terutama pada musim kemarau.

\section{Analisis sumberdaya air}

Perencanaan pengembangan sungai dan sumber daya air lainnya secara garis besarnya adalah pengembangan sumber air dalam rangka mendukung bidang ekonomi lainnya, seperti pengembangan industri dan pertanian dalam daerah pengaliran sungai dan sekitarnya. Rencana ini akan menetapkan sasaran-sasaran tertentu yang terdiri dari pengendalian banjir, pembangkit tenaga listrik, irigasi, air bersih, air industri, dan lalu lintas sungai. Tingkat pengembangan sungai biasanya dibatasi oleh berbagai kondisi, seperti kondisi geografis, teknik, sosial dan ekonomi dan harus ditetapkan sedemikian rupa dengan sepenuhnya mempertimbangkan kebutuhan masyarakat, sehingga perencanaan yang akan di terapkan dapat mendorong peningkatan kemajuan ekonomi secara maksimum.

Penutupan vegetasi alam memainkan peran penting dalam mengatur perilaku sistem drainase air. Terutama "efek spons" yang menyekap air hujan dan air itu ditahan oleh hutan dan vegetasi lainnya sehingga mengalir keluar lebih lambat dan merata kedalam sistem sungai, mengurangi kecenderungan banjir pada periode hujan lebat dan melepaskan air terus menerus selama periode musim kemarau. Fungsi ini hilang apabila vegetasi kawasan tangkapan di daratan tinggi menjadi rusak. Menurut Purwono (1998), diseluruh daerah tropika, 90 persen dari jumlah petani bertani di lembah daratan rendah, sehingga mereka bergantung pada kegiatan 10 persen populasi yang tinggal di daerah aliran sungai. Persediaan air sangat penting bagi kehidupan manusia, sehingga perlindungan dari vegetasi alam bernilai lebih tinggi dibandingkan penggunaan lainnya. Jadi kawasan khusus harus dicadangkan sebagai cagar hidrologi. Seleksi kawasan perlu dilindungi bagi pelestarian fungsi hidrologi akan bergantung pada empat pertimbangan utama, yaitu kepekaan kawasan tangkapan terhadap erosi, kepekaan sungai terhadap banjir, ketersediaan air musiman dan kepentingan sosio-ekonomi aliran sungai tertentu.

Perubahan bentuk pengunaan lahan dapat berdampak negatif terhadap kondisi hidrologi di suatu wilayah, baik secara kuantitatif dan kualitatif. Dampak tersebut terlihat pada air permukaan dan air tanah, bahkan pada air hujan dampak ini pun dapat 
terjadi. Secara umum dampak ini dapat dikaji dari perubahan daur hidrologi, namun sifatnya dapat berupa dampak mikro maupun makro. Hutan sangat berperan dalam menjaga hidroorologis, bahkan dapat mengubah kondisi iklim suatu wilayah, walapun hanya bersifat sebagai iklim mikro.

Terjadinya perubahan fungsi lantaran sungai menjadi lahan usaha seperti pertambangan dan pemukiman manusia yang semakin banyak serta makin meluasnya lahan tangkapan air yang di peruntukan bagi kegiatan produksi mengakibatkan berkurangnya kapasitas aliran sungai dan berkurangnya lahan penampung air merupakan salah satu penyebab terjadinya banjir dan merosotnya sumberdaya air.

\section{Perencanan Pengembangan dan Alokasi Pemanfaatan Ruang Perencanaan Pengembangan Wilayah}

Penataan ruang wilayah, daerah dan kota merupakan salah satu optimasi pemanfaatan ruang untuk mencapai kesejahteraan masyarakat tanpa mengesampingkan konservasi dan kelestarian tata lingkungan. Hal ini dapat dilakukan melalui pengaturan program dan proyek secara efisien, keterikatan antar fungsi kegiatannya, keterpaduan dalam pendanaan dan penanganannya, serta kelembagaannya bagi pelaksanaannya. Sugandhy (1984), menyebutkan bahwa prosesproses perencanaan ekonomi, sosial, kelembagaan dan teknologi serta fisik dan lingkungan itu berkait satu sama lain sebagai suatu fungsi mekanisme pengembangan wilayah, daerah dan kota.

Perencanaan tata ruang wilayah adalah upaya merumuskan usaha pemanfaatan ruang atau lahan secara optimal dan penataannya secara efisien bagi kegiatan usaha manusia di wilayahnya; berupa pembangunan sektoral, daerah masyarakat dalam mewujudkan tingkat kesejahteraan masyarakat yang ingin dicapai pada kurun waktu tertentu. Sedangkan produk perencanaan berupa rencana penataan ruang wilayah untuk daerah pekotaan dan pedesaan dengan indikasi strategi pembangunan dan program yang di prioritaskan.

Terjadinya ruang-ruang yang diperuntukkan bagi kegiatan manusia disebabkan adanya sumberdaya alam, sumberdaya manusia dan sumberdaya buatan.
Berdasarkan pengertian tersebut, maka sistem ruang dalam wilayah nasional dapat dibagi habis atas tiga lingkup makro, yaitu kawasan lautan, daratan dan angkasa.

Penataan ruang adalah suatu usaha manusia yang diwujudkan berupa struktur ruang yang mengambarkan ikatan manfaat ruang yang terpadu bagi sektor-sektor pembangunan baik bidang ekonomi, sosial budaya, hankamnas dalam membina hidup manusia berserta segala isinya. Ikatan manfaat ruang yang terpadu meliputi pengaturan tata ruang perencanan fisik, perencanaan sosial, perencanan ekonomi, perencanan kelembagan (institutional) bagi kehidupan manusia dan lingkungan yang selaras, serasi dan seimbang. Pengaturan memerlukan dimensi waktu untuk mengarahkan kegiatan manusia agar sesuai dengan keseimbangan lingkungan hidup yang merupakan kesatuan ruang dengan semua benda, daya, keadaan dan makluk hidup, termasuk manusia dan perilakunya, yang mempengaruhi kelangsungan kehidupan dan kesejahteraan mahluk hidup.

\section{Alokasi Pemanfaatan Ruang}

Didalam penjelasan UU No. 26 Tahun 2007 tentang penataaan ruang, ditegaskan pada arahan pemanfaatan ruang tahun 2001 dibedakan kedalam kelompok kawasan fungsi lindung (non budidaya) dan kawasan budidaya. Berdasarkan hasil kesepakatan antar instansi terkait (sektoral) yang dituangkan kedalam peta paduderasi RTRW Kota Palangka Raya tahun 2001, diketahui bahwa arahan pemanfaatan ruang pada umumnya adalah kawasan lindung dan kawasan budidaya. Berdasarkan hasil tumpang susun peta fungsi kawasan hutan dengan peta vegetasi dan penggunaan lahan tahun 2008 serta peta RTRW Kota Palangka Raya. Peta ini menggambarkan zonasi-zonasi yang berisi areal yang menggambarkan arahan pemanfaatan ruang untuk berbagai penggunaan khususnya yang dioptimasikan untuk kawasan lindung dan kawasan budidaya.

Berdasarkan kajian teknis kehutanan dalam rangka pemantapan fungsi kawasan hutan, dalam pelaksanaan tata batas dan deleniasi di lapangan perlu memperhatikan hak-hak yang sudah ada (kondisi eksisting) yang tidak bertentangan dengan ketentuan yang berlaku, misalnya areal pemukiman dan 
infrastruktur pemerintah seyogianya dikeluarkan atau di encalve dari kawasan hutan termasuk infrastruktur jalan, kantor dan gedung milik pemerintah juga sebaiknya di enclave dari kawasan hutan. Luasan zonasi masing-masing areal pada peta arahan penyusunan RTRWK tersebut dapat dilihat pada Tabel 3.

Tabel 3. Luas areal masing-masing zonasi untuk arahan tata ruang wilayah di Kota Palangka Raya

\begin{tabular}{lrr}
\hline \multirow{2}{*}{ Uraian Fungsi Kawasan } & \multicolumn{2}{c}{ Luas } \\
\cline { 2 - 3 } & \multicolumn{1}{c}{ Ha } & \multicolumn{1}{c}{$\%$} \\
\hline Kawasan Lindung & 0 & 0 \\
1. Hutan Lindung & 47.316 & 17,67 \\
2. Taman Nasional Sebangau & 533 & 0,20 \\
3. Taman Wisata & 1.137 & 0,42 \\
4. Taman Hutan Raya & & \\
Kawasan Budidaya & 44.791 & 16,72 \\
1. Hutan Produksi Tetap & 90.401 & 33,75 \\
2. Hutan Produksi Konversi & 83.673 & 31,24 \\
3. Areal Penggunaan Lain & 267.851 & 100 \\
\hline \multicolumn{1}{c}{ Jumlah } & & \\
\hline
\end{tabular}

Tabel 3 menunjukkan di wilayah Kota Palangka Raya tidak terdapat hutan lindung namun kawasan lindung masih terdapat pada zona Taman Nasional, Taman Wisata dan Taman Hutan Raya. Peta Arahan Fungsi Kawasan Hutan ini dapat dilihat pada Gambar 5.

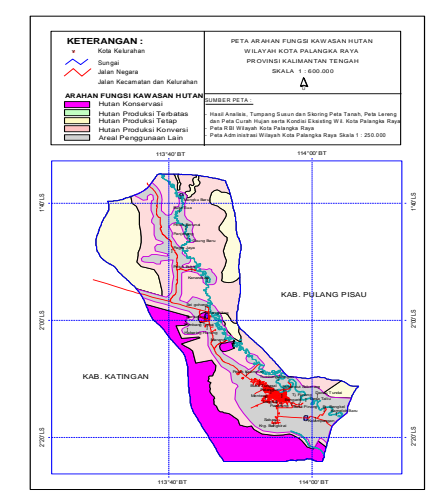

Gambar 5.Peta Arahan Fungsi Kawasan Hutan Wilayah Kota Palangka Raya.

\section{KESIMPULAN}

1. Fungsi kawasan hutan yang optimal di Kota Palangka Raya sebsesar $68,76 \%$, terbagi atas $17,67 \%$ Taman Nasional Sebangau, 0,207\% Taman Wisata, 0,42\% Taman Hutan Raya, 16,72\% Hutan Produksi Tetap, $33,75 \%$ Hutan Produksi Konversi.

2. Arahan zonasi untuk penyusunan rencana tata ruang wilayah Kota Palangka Raya adalah: $18,29 \%$ zonasi untuk kawasan lindung, 50,47\% kawasan budidaya kehutanan (KBK) dan 31,24\% kawasan budidaya non kehutanan (KBNK) atau Areal Penggunaan Lain (APL).

\section{DAFTAR PUSTAKA}

Bakosurtanal, 1992, Petunjuk penyajian peta untuk informasi lingkungan,

Bakosurtanal, Jakarta.

Departemen Kehutanan. (1999). UndangUndang Nomor 41 Tahun 1999 tentang Kehutanan. Jakarta.

Departemen Kehutanan. (2000). Petunjuk teknis Penafsiran Citra Satelit Lansdsat ETM+7 Badan Planologi Kehutanan. Departemen Kehutanan. Jakarta.

Departemen Kehutanan. (2002). Statistik Kehutanan Indonesia 2001. Departemen Kehutanan. Jakarta.

Departemen Kehutanan. (2002). Peraturan Pemerintah No. 63 Tahun 2002 tentang Hutan Kota. Jakarta.

Departemen Pekerjaan Umum. (2007). Undang-Undang Nomor 24 Tahun 1992 tentang Penataan Ruang. Jakarta.

Departemen Pekerjaan Umum. (2007). Undang-Undang Nomor 26 Tahun 2007 tentang Penataan Ruang. Jakarta.

Departemen Pekerjaan Umum. (2007). Peraturan Menteri Pekerjaan Umum No. 1 Tahun 2007 tentang Penataan Ruang Terbuka Hijau di Kawasan Perkotaan. Jakarta.

Departemen Pekerjaan Umum. (2007). Peraturan Menteri Pekerjaan Umum No. 20/PRT/M/2007 tentang Tehnik Analisi Aspek Fisik dan Lingkungan dalam Rencana Tata Ruang Wilayah. Jakarta.

Departemen Pekerjaan Umum. (2008). Peraturan Menteri Pekerjaan Umum No. 5/PRT/M/2008 tentang Penyediaan dan Pemanfaatan Ruang Terbuka Hijau di Kawasan Perkotaan. Jakarta.

Departemen Pertanian. (1982). Surat Keputusan Menteri Pertanian Nomor 759/Kpts/Um/10/1982 tanggal 12 Oktober 1982 tentang Penunjukkan Areal Hutan di Wilayah Provinsi Daerah Tingkat I Kalimantan Tengah. Jakarta.

Purwono, R, 1998, Keberadaan Hutan dalam mengatur Sistem Tata Air dan Areal di Sekitarnya, Jakarta. 
Ridwan, W, 2000, Pengusahaan Ekowisata, Pustaka Pelajar, Yogyakata.

Rikimaru, A dan Miyatake, S., 1996, Development of Forest Canopy Density Mapping and Monitoring Model using Indices of Vegetation, Bare soil and Shadow, Hosei University, Tokyo.

Sitorus, R.S.P., 1985, Evaluasi Sumber Daya Lahan, Tarsito, Bandung.
Sugandhy, A., 1984, Peranan Ruang Wilayah, Daerah dan Kota, Majalah Prisma No. 6 Tahun XIII - 1984, LP3ES, Jakarta.

Suparmoko, M., 1995, Ekonomi Sumberdaya Alam dan Lingkungan (Suatu Pendekatan Teoritis), Yogyakarta. 